\title{
Content of heavy metals in the bottom sediments of the wastewater of the processing enterprise
}

\author{
Olga Kovaleva ${ }^{1, *}$, Natalia Sannikova ${ }^{1}$, and Oleg Ilyasov ${ }^{2}$ \\ ${ }^{1}$ Northern Trans-Ural State Agricultural University, Russia \\ ${ }^{2}$ Ural State University of Railway Transport, Russia
}

\begin{abstract}
Wastewater contains stable and unstable pollutants. In the process of self-cleaning, a large amount of bottom sediments accumulates, especially in artificially created storage ponds. As a result of the increasing load on this type of water bodies and the accumulation of bottom sediments, the self-purification ability is sharply reduced, which entails an additional load on the environment. The use of bottom sediments for biological reclamation is allowed after the establishment of the hazard class in accordance with the current regulatory documents and taking measures to neutralize them. The purpose of this separate fragment of work was to study the total content of heavy metals in the bottom sediments of storage ponds of a milk processing enterprise and determine the possibility of their further use. As a result of the data obtained, it can be concluded that the lead content was $14.6-17.3 \mathrm{mg} / \mathrm{kg}$, depending on the depth of the bottom sediment sampling layer. At a sampling depth of 0.5-1.0 meters, the lead content was maximum and exceeded the clarke values of the element by $8.1 \%$. There is a 2 time excess of the clarke values for cadmium at a depth of 1.0-1.5 meters. Indicators for zinc and copper were $12.4-14.1 \mathrm{mg} / \mathrm{kg}$ and $5.9-9.8 \mathrm{mg} / \mathrm{kg}$, respectively, and did not go beyond the threshold limits of the compared values. The research results allow concluding that the bottom sediments of the storage ponds of the milk processing enterprise are not toxic. Therefore, they can be used in the composition of soil.
\end{abstract}

\section{Introduction}

The resistance of ecosystems to anthropogenic impacts depends on their selfpurification ability. The contribution of individual processes to the self-purification of water depends on the nature of pollutants, temperature, species composition of microbiocenosis and hydrochemical parameters [1,2].

Food industry enterprises are one of the most resource-intensive ones in agribusiness, whose activities are accompanied by a high consumption of energy and water resources per unit of production, and a significant amount of polluted wastewater is generated, which have a negative impact on the environment. Along with this, they have great potential for

\footnotetext{
*Corresponding author: lemur.84@mail.ru
} 
introducing the best available technologies and increasing the efficiency of using natural resources $[3,4]$.

Wastewater from food processing plants contains stable and unstable contaminants. In most cases, the nature and concentration of substances do not change over time [5]. The concentration of some naturally stable substances may decrease due to their volatility, reaction with other substances, or due to biochemical processes (destruction of organic substances) [6-8]. As a result of the total influence of these processes, there is a decrease in the concentration of the incoming substances in the reservoir until complete disappearance of some of them, or, in other words, self-purification. In the process of self- purification, a large amount of bottom sediments accumulates, especially in artificially created storage ponds. As a result of the increasing load on this type of water bodies and the accumulation of bottom sediments, the self-purification ability sharply decreases $[9,10]$. Therefore, it becomes necessary to look for possible ways of using the sediment, but this is complicated by the fact that it can also contain a large amount of non-degradable pollutants.

The use of bottom sediments for biological reclamation is allowed after the establishment of the hazard class in accordance with the current regulatory documents and taking measures to neutralize them $[11,12]$.

The purpose of this separate fragment of the work was to study the total content of heavy metals in the bottom sediments of storage ponds of the milk processing enterprise and determine the possibility of their further use.

\section{Materials and Methods}

The object of the study was the bottom sediments of the storage ponds of the milk processing enterprise.

Based on the Guidelines for the implementation of state monitoring of water bodies [13, 14] in terms of organizing and conducting observations of the content of pollutants in bottom sediments of water bodies, Order No. 112 dated 24.02.2014, for a general description of the characteristics of bottom sediments, their visual and physical characteristics, temperature, and $\mathrm{pH}$ values were determined. Also, samples were taken for laboratory research.

To determine the hazard rate of bottom sediments in accordance with section II of the Order of the Ministry of Natural Resources of Russia dated December 4, 2014 №536 “On approval of the criteria for classifying waste to I-V hazard classes according to the degree of negative environmental impact", samples of bottom sediments were taken. Samples of soil, subsoil and bottom sediments were taken (Fig. 1) in accordance with the Russian State Standard GOST 12071-2014 by the point method using a soil sampler every $0.5 \mathrm{~m}$ during vertical drilling at 3 control points (Fig. 1) and placed in sealed bags (Fig. 2). 

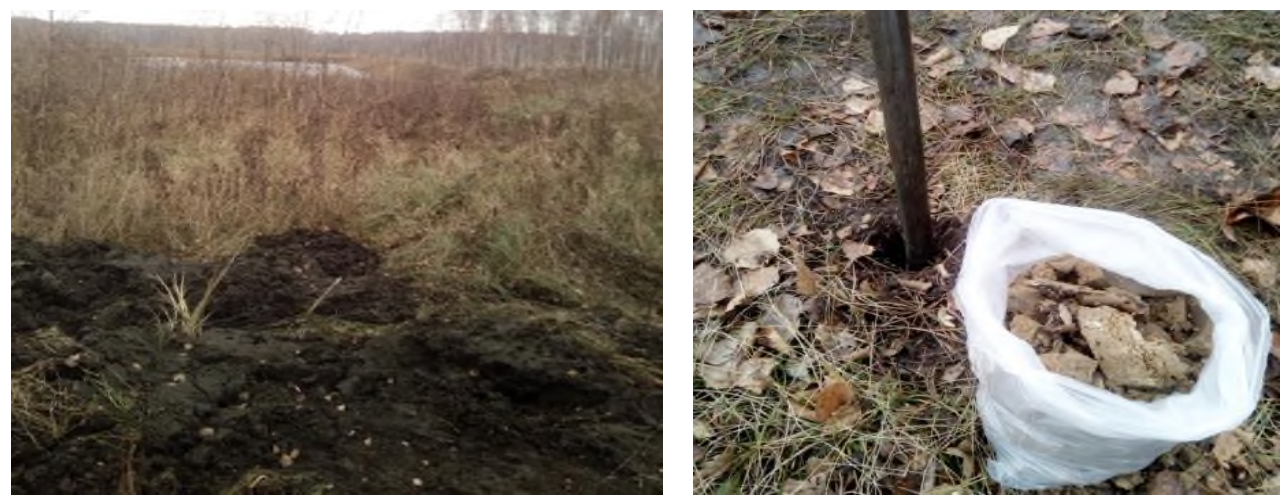

Fig. 1. Sampling points for subsoil and bottom sediments.

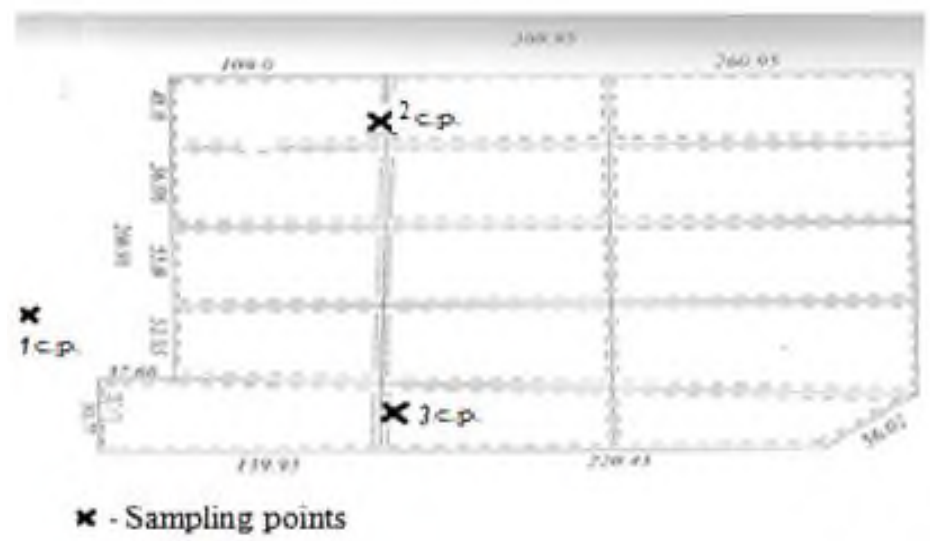

Fig. 2. Scheme of sampling points (c.p.) for bottom sediments.

In bottom sediments, on the basis of the Approximate list of pollutants that can accumulate in bottom sediments of water bodies of the dairy processing industry, the following contents were determined: $\mathrm{pH}$, organic matter, sulfur, calcium, magnesium, nitrogen, phosphorus, potassium, including heavy metals, the indicators of which are necessary for this stage of research.

Laboratory research was carried out in the laboratory of the Institute of Applied Agricultural Research and Development of the FSTBEI HE Northern Trans-Ural State Agricultural University.

\section{Results/Discussion}

The use of bottom sediments for biological reclamation or other purposes is allowed after the hazard class is established in accordance with the current regulatory documents and measures are taken to neutralize them.

The content of heavy metals in bottom sediments is one of the most objective and reliable indicators of pollution of aquatic systems $[15,16]$.

The obtained data on the content of heavy metals in the bottom sediments of storage ponds presented in Table 1 were compared with the clarke value and freshwater bottom sediments. 
Table 1. Content of heavy metals in bottom sediments, $\mathrm{mg} / \mathrm{kg}$.

\begin{tabular}{|l|c|c|c|c|c|}
\hline \multirow{2}{*}{$\begin{array}{c}\text { Chemical } \\
\text { element }\end{array}$} & \multicolumn{2}{|c|}{ Content in bottom sediments } & Clarkes of the & Freshwater \\
\cline { 2 - 4 } & $\mathbf{1}$ & $\mathbf{2}$ & $\mathbf{3}$ & lithosphere $*$ & 16 \\
\hline Lead & 14.6 & 17.3 & 15.2 & 0.13 & 0.35 \\
\hline Cadmium & 0.03 & 0.03 & 0.26 & 83 & 110 \\
\hline Zinc & 14.1 & 13.6 & 12.4 & 47 & 43 \\
\hline Copper & 7.8 & 9.8 & 5.9 & 47 \\
\hline
\end{tabular}

Note $^{*}$ - clarkes of the lithosphere (A.P. Vinogradov, 1987), ** - freshwater bottom sediments (U. Forstner 1977).

As a result of the data obtained, it can be concluded that the content of lead was 14.6$17.3 \mathrm{mg} / \mathrm{kg}$, depending on the depth of the layer of bottom sediments selection. At a sampling depth of 0.5-1.0 meters, the lead content was maximum and exceeded the element's clarke values by $8.1 \%$. There is a 2 time excess of the clarke values for cadmium at a depth of 1.0-1.5 meters. Indicators for zinc and copper were 12.4-14.1 mg/kg and 5.9$9.8 \mathrm{mg} / \mathrm{kg}$, respectively, and did not go beyond the threshold limits of the compared values.

According to the concentration of heavy metals, precipitation for agricultural use is divided into two groups. Sediments with a higher concentration of heavy metals, but at the same time corresponding to IV-V classes of environmental hazard, are allowed for use in technical reclamation.

The gross content of heavy metals at a depth of up to 1.5 meters is presented in Table 2 .

Table 2. Gross content of heavy metals $(\mathrm{mg} / \mathrm{kg})$.

\begin{tabular}{|c|c|c|c|c|c|c|c|c|}
\hline \multirow{5}{*}{ Indicator } & \multicolumn{6}{|c|}{ Samples } & \multirow{4}{*}{\multicolumn{2}{|c|}{$\begin{array}{l}\text { Concentration of dry } \\
\text { matter, } \mathrm{mg} / \mathrm{kg} \text {, no } \\
\text { more, for group of } \\
\text { sediments }\end{array}$}} \\
\hline & \multicolumn{3}{|c|}{ background site } & \multirow{2}{*}{\multicolumn{3}{|c|}{$\begin{array}{l}\text { experimental site } \\
\text { bottom sediments }\end{array}$}} & & \\
\hline & \multirow{3}{*}{ soil } & \multirow{3}{*}{$\begin{array}{c}\text { soil and } \\
\text { subsoil }\end{array}$} & \multirow{3}{*}{ subsoil } & & & & & \\
\hline & & & & \multirow{2}{*}{1} & \multirow{2}{*}{2} & \multirow{2}{*}{3} & & \\
\hline & & & & & & & I & II \\
\hline $\mathrm{Pb}$ & 16.3 & 16.4 & 17.1 & 14.6 & 17.3 & 15.2 & 250 & 500 \\
\hline $\mathrm{Cd}$ & 0.03 & 0.03 & 0.25 & 0.03 & 0.03 & 0.26 & 15 & 30 \\
\hline $\mathrm{Zn}$ & 24.7 & 21.7 & 16.3 & 14.1 & 13.6 & 12.4 & 1750 & 3500 \\
\hline $\mathrm{Cu}$ & 10.3 & 8.1 & 9.7 & 7.8 & 9.8 & 5.9 & 750 & 1500 \\
\hline
\end{tabular}

The table shows that in the samples under study, none of the elements exceeds the permissible bulk content of heavy metals. It is much lower for all elements than the criteria of the first group. This is important to note, since if the content of at least one of the standardized elements exceeds its permissible level for group I, then sediments is attributed to group II.

Sediments of groups I and II are used in industrial floriculture, green construction, forest and ornamental nurseries, for biological reclamation of disturbed lands and landfills of municipal solid waste (GOST 17.4.3.07-2001).

\section{Conclusion}

The research results allow concluding that bottom sediments of storage ponds are not toxic. Therefore, they can be used in the composition of soil and subsoil. In the case of nonagricultural use of bottom sediments, the application rates should be determined by crop cultivation technologies and areas of reclamation (GOST R 54534-2011). General requirements for the use of sediments for reclamation of disturbed lands are determined by GOST 17.5.3.04.

The procedure for using bottom and silt sediments as a component of plant soil is determined by the technological regulations, which are developed by specialized 
organizations taking into account regional and local conditions, including soil properties and hydrological regime, the content of normalized pollution in sediments and soil, total and mineral nitrogen, phosphorus, potassium, and peculiarities of crop cultivation.

\section{References}

1. S. Koshelev, O. Ilyasov, O. Romanova, Anthropogenic impact on water bodies within the area of activities of livestock complexes. Ecological Agriculture and Sustainable Development (South Ural State University, 2019)

2. M.L. Dongarra, V. Rizzello, L. Muccio et. al., Current Allergy and Asthma Reports (2013) DOI: 10.1007/s11882-012-0313-0.

3. D.V. Eremina, D.I. Eremin, Fertility of agrogenic and postagrogenicchernozems of western siberia. IOP Conference Series: Earth and Environmental Science. 12th International Scientific Conference on Agricultural Machinery Industry, INTERAGROMASH (2019)

4. O.V. Kovaleva, N.V. Sannikova, Microbiological treatment system of storage ponds. E3S Web of Conferences: The conference proceedings Innovative Technologies in Environmental Science and Education (Don State Technical University, Rostov-onDon, 2019)

5. D.M. Lilly, R.H. Stillwell, Science 147(3659), 747-748 (1965) DOI: 10.1126/science.147.3659.747.

6. N.V. Mayachkina, M.V. Chugunova, Biology. Vestnik of Lobachevsky University of Nizhni Novgorod 1 (2009)

7. N. Gruzdeva, D. Eremin, Influence of long-term plowing on water permeability of light-gray forest soils of taiga-forest zone of western Siberia. In collection: IOP Conference Series: Earth and Environmental Science. 12th International Scientific Conference on Agricultural Machinery Industry, INTERAGROMASH (2019)

8. A.S. Motorin, A.V. Iglovikov, Assessment of group composition of peat organic matter for industrial processing. IOP Conference Series: Earth and Environmental Science. International Conference on Innovations and Prospects of Development of Mining Machinery and Electrical Engineering, IPDME 2018 - Mining Machines, Technologies of Processing and Transportation. Series "IOP Conference Series: Earth and Environmental Science" (2018)

9. O.V. Kovaleva, N.V. Sannikova, KnE Life Sciences (2019) DOI $10.18502 / \mathrm{kls} . v 4 \mathrm{i} 14.5598$

10. O.R. lyasov, Basic state requirements for environmental aspects to enterprises in the Russian Federation. ENVIRONMENTAL management \& audit 1. Tempus project Recoaud. Czestochowa (2016)

11. N.V. Gaponov, O.P. Neverova, O.V. Gorelik, A.V. Stepanov, Probiotics and animal feed in primates feeding. E3S Web of Conferences (2020)

12. N. Gavrilova, N. Chernopolskaya, M. Rebezov, D. Moisejkina, I. Dolmatova, I. Mironova, G. Peshcherov, O. Gorelik, M. Derkho, International Journal of Recent Technology and Engineering 8(2) (2019)

13. A.S. Krivonogova, I.M. Donnik, A.G. Isaeva, K.V. Moiseeva, Agrarian Bulletin of the Urals 9(200), 42-47 (2020) 
14. E.A. Krasnoperova, I.M. Donnik, Yu.A. Yuldashbaev, M.G. Leshcheva, V.N. Kulakov, S.O. Chylbak-ool, Bulletin of the National Academy of Sciences of the Republic of Kazakhstan 6(388) (2020)

15. Kh.E. Flefel, M.O. Gutova, I.M. Donnik, Yu.G. Gribovskiy, Agrarian Bulletin of the Urals 6(185) (2019)

16. H.E. Flefel, I.M. Donnik, D.Y. Nokhrin, Egyptian Journal of Aquatic Biology and Fisheries 23(4) (2019) 